\title{
Uptake of Reconstituted Na,K-ATPase Vesicles by Isolated Lymphocytes Measured by FACS, Confocal Microscopy and Spectrofluorometry
}

\author{
Beatrice M. Anner* and B. Volet \\ Department of Pharmacology, Geneva University Medical School, $\mathrm{CH}$ - \\ 1211 Geneva 4, Switzerland; E-mail: beatrice.anner@span.ch
}

\begin{abstract}
$\mathrm{Na}$,K-ATPase (EC 3.6.1.37, Na,K-ATPase) is a fundamental vital membrane transport and receptor system which, after biosynthesis, is exported to the plasma membrane in inside-out vesicles. $\mathrm{Na}, \mathrm{K}-\mathrm{ATPase}$ can be extracted form the natural membrane and inserted into artificially formed phosphatidylcholine vesicles (liposomes). The ultrastructure of the reconstituted vesicles has been fully described. In the present work, the $\mathrm{Na}, \mathrm{K}-$ ATPase-vesicles were labeled with fluorescent tracers either in their water or membrane phase, incubated with freshly isolated human lymphocytes, and the resulting cellular fluorescence measured with fluorescence activated cell sorting (FACS), confocal microscopy and spectrofluorometry. The FACS data show that all lymphocytes take up $\mathrm{Na}, \mathrm{K}-\mathrm{ATPase}$-vesicles in a doseand temperature-dependent fashion. Three-dimensional analysis of the fluorescence by confocal microscopy reveals that the fluorescence is contained within the cells. Quantitative determination by spectrofluorometry indicates that depending on the
\end{abstract}

*Author to whom all correspondence and reprint requests should be addressed. 
vesicle/cell ratio, a single lymphocyte takes up 650 to 36,500 vesicles within $30 \mathrm{~min}$ at $37^{\circ} \mathrm{C}$ together with up to about 200,000 renal $\mathrm{Na}$,K-ATPase molecules.

Index Entries: Reconstituted Na,K-ATPase-vesicles; lymphocytes; uptake; FACS; confocal microscopy; spectrofluorometry; quantitative analysis.

\section{INTRODUCTION}

The cytoplasm of eukaryotic cells is rich in vesicles of $20-100 \mathrm{~nm}$ diameter. They serve as shuttles for neurotransmitters of hormones or they deliver or retrieve from the plasma membrane the integral proteins $(1,2)$. The $\mathrm{Na}, \mathrm{K}$-ATPase (Na,K-ATPase) or sodium pump is a fundamental membrane system that is responsible for the electrolyte balance of the organism, organs, cells, and organelles (3); it expels $\mathrm{Na}$ from the cell and replaces it by $\mathrm{K}$ by an electrogenic process ( $3 \mathrm{Na}$ out vs $2 \mathrm{~K}$ in) coupled to hydrolysis of 1 ATP molecule. The process is modulated by an inhibitory extracellular receptor for cardioactive steroids such as ouabain and their presumed endogenous analogs (4). The resulting transmembrane ion gradient and membrane potential is underlying cell excitability, impulse conduction (5), and muscle contraction (6) in nerve and muscle. In epithelia, the polarized localization of the $\mathrm{Na}, \mathrm{K}-\mathrm{ATP}$ ase leads to transepithelial $\mathrm{Na}$ transport and is the motor of $\mathrm{Na}$ reabsorption, e.g., in the kidney.

Vesicles similar to the ones found within cells can be formed artificially and integral membrane proteins, e.g., Na,K-ATPase, inserted into their membranes (7). Their ultrastructure has revealed resemblance in size and aspect $(8,9)$ to natural intracellular vesicles as both types are reaching apparently the same minimal energy state because of their like chemical composition (10). The artificially formed $\mathrm{Na}, \mathrm{K}$-ATPase vesicles carry $50 \%$ of the reconstituted $\mathrm{Na}, \mathrm{K}$ ATPase in inside-out orientation and are, therefore, partially analogous to the natural intracellular inside-out vesicles delivering the $\mathrm{Na}, \mathrm{K}-\mathrm{ATP}$ ase to the plasma membrane. Therefore, it should be possible to let them enter into the cell where they are predicted to join the normal intracellular vesicle traffic.

Lymphocytes take up externally added phospholipid vesicles or liposomes (11-13). Liposome uptake involves binding to the cell surface followed by endocytosis (14). Recently it was shown that they are able also to take up nanospheres without apparent toxicity 
(15). However, it has not been examined whether isolated human lymphocytes take up vesicles containing foreign membrane proteins.

In the present work $\mathrm{Na}, \mathrm{K}$-ATPase-vesicles are labeled by fluorescent markers of the membrane or of the water phase and their uptake by isolated human lymphocytes is demonstrated by three different techniques. FACS analysis shows vesicle uptake by all cells; confocal microscopy visualizes the vesicle entry on a single cell level and spectrofluorometry reveals that the cells are able to take up about three times their own amount of membrane surface and about 10 times their own amount of $\mathrm{Na}, \mathrm{K}-\mathrm{ATPase}$ protein within $30 \mathrm{~min}$ at $37^{\circ} \mathrm{C}$.

\section{METHODS}

\section{Materials, Isolation of Na,K-ATPase, and Biochemical Measurements}

Phosphate buffered saline (PBS), RPMI-1640 medium, and Hank's balanced salt solution (HBSS) were from Tecnomara (Zürich, $\mathrm{CH})$. Phosphatidylcholine (grade II) was from Lipid products (Nutfield, UK); CF was purchased from Fluka (Buchs, CH). N-(5fluoresceinthiocarbamoyl)1,2-dihexadecanoyl-sn-glycero-3-phosphoethanolamine triethyl ammonium salt (Fluo-PE) was from Molecular Probes (Eugene, OR). LeucoSep tubes (Esquire Chemie AG, Zürich, $\mathrm{CH}$ ) were used for the isolation of peripheral blood mononuclear cells. Na,K-ATPase was purified from the outer medulla of rabbit kidneys to a specific activity of 1200 to $1800 \mu \mathrm{mol} \mathrm{Pi} / \mathrm{mg}$ protein $/ \mathrm{h}$ by treatment with SDS and centrifugation across a sucrose gradient (16). The Na,K-ATPase activity was measured by the linked-enzyme assay (17) and the protein was determined as described by Smith et al. (18). The Na,K-ATPase was separated into $\alpha$ and $\beta$ subunits by PAGE, which together make up about $90 \%$ if the protein as estimated by Coomassie blue staining and laser densitometry (17).

\section{Insertion of Na,K-ATPase into Vesicles}

Vesicles are formed by making use of the fact that phosphatidylcholine (PC), dissolved in a $1 \%$ cholate solution, forms closed vesicles upon detergent removal by dialysis (8). Membrane fragments containing the purified $\mathrm{Na}, \mathrm{K}-\mathrm{ATPase}$ are treated with $1 \%$ cholate to disrupt the continuity of the lipid bilayer and single $\mathrm{Na}, \mathrm{K}-\mathrm{ATP}$ ase molecules obtained in the supernatant of a $100,000 \mathrm{~g}$ centrifugation ("soluble" $\mathrm{Na}, \mathrm{K}-\mathrm{ATPase}$ ). When the "soluble" $\mathrm{Na}, \mathrm{K}-$ 
ATPase is added to the PC solution and the cholate removed by dialysis, $\mathrm{Na}, \mathrm{K}$-ATPase spontaneously inserts into the lipid bilayer and is seen by freeze fracture electron microscopy at regular distances $(8,9)$ in the vesicles indicating noninteraction between the $\mathrm{Na}, \mathrm{K}-\mathrm{ATPase}$ molecules. The number of reconstituted $\mathrm{Na}$, K-ATPase molecules is directly proportional to the protein/lipid ratio used for reconstitution and statistical analysis of the intramembrane particle distribution on concave and convex fracture faces has revealed random orientation (9).

A lipid-cholate stock solution was prepared as follows: $60 \mathrm{mg}$ PC in $600 \mu \mathrm{L}$ chloroform-methanol was dried under a slow, steady stream of ultrapure $\mathrm{N}_{2}$ in a 50-mL round-bottomed flask fixed to a Büchi minirotary apparatus in a water bath at $25^{\circ} \mathrm{C}$ for about $30 \mathrm{~min}$ in the dark until a thin film was formed to which $3 \mathrm{~mL}$ dried ether was added; this process was repeated. The third film was formed first without $\mathrm{N}_{2}$ blow to avoid solvent capping and was then extensively dried by $\mathrm{N}_{2}$ for $90 \mathrm{~min}$ at $25^{\circ} \mathrm{C}$, followed by $2 \mathrm{~min}$ at $30^{\circ} \mathrm{C}$. Then, $3 \mathrm{~mL}$ of a solution containing $50 \mathrm{mM} \mathrm{NaCl}, 50 \mathrm{mM} \mathrm{KCl}, 5 \mathrm{mM}$ $\mathrm{MgCl}_{2}, 1 \mathrm{mM}$ EDTA, $30 \mathrm{~m} M$ L-histidine, and 1\% Na-cholate, pH 7.2, (solution A) was added to the lipid film and the flask rotated until a clear solution was obtained from which $100 \mu \mathrm{L}$ aliquots were put under nitrogen and stored at $-70^{\circ} \mathrm{C}$. Na,K-ATPase $(600 \mu \mathrm{g}$ protein) was pelleted at $100,000 \mathrm{~g}$ for $15 \mathrm{~min}$ to in a Beckman airfuge at $0^{\circ} \mathrm{C}$, resuspended in $100 \mu \mathrm{L}$ of solution $\mathrm{A}$ and again centrifuged for 15 min at $100,000 g$; the $\mathrm{Na}, \mathrm{K}-\mathrm{ATPase}$ activity and protein content of the supernatant containing the "soluble" $\mathrm{Na}, \mathrm{K}-\mathrm{ATP}$ ase were determined and the remaining $80 \mu \mathrm{L} \mathrm{Na}, \mathrm{K}-\mathrm{ATPase}$ solution added to $80 \mu \mathrm{L}$ of PC solution; the $\mathrm{Na}, \mathrm{K}-\mathrm{ATPa} e$ activity after PC addition was determined, the PC-Na,K-ATPase solution added to EDTA treated sterile dialysis tubing, and the cholate removed during $15 \mathrm{~h}$ at $0^{\circ} \mathrm{C}$ in $100 \mathrm{~mL}$ cholate-free solution A (solution B).

\section{Fluorescent Labeling of the Vesicles}

The vesicles were labeled in two manners: in the water phase by carboxyfluorescein (CF) according to published procedures $(19,20)$ or in the membrane phase by Fluorescein-phosphatidylethanolamine (Fluo-PE). For CF-labeling $200 \mathrm{mM} \mathrm{CF}$ was added prior to dialysis. The $\mathrm{pH}$ was adjusted to 7.2 by $1 \mathrm{M} \mathrm{NaOH}$, which brought $330 \mathrm{mM}$ additional $\mathrm{Na}$ ions to the solution. The dialysis temperature was raised to $20^{\circ} \mathrm{C}$ to prevent crystalization; to eliminate the exter- 
nal $\mathrm{CF}$ after dialysis, the liposomes were centrifuged four times for $60 \mathrm{~min}$ at $100,000 \mathrm{~g}$ in a Beckman airfuge at $0^{\circ} \mathrm{C}$ and resuspended in $200 \mu \mathrm{L}$ solution $\mathrm{B}$. The tightness of the liposomes was controled by incubating them in the presence and absence of detergent and determining the entrapped and released CF by spectrofluorometry taking advantage of the CF selfquenching $(20,21)$. The entrapped fluorescence measured after detergent-lysis was found to be directly proportional to the liposome concentration in confirmation that there was no contaminating external dye. The quenching of the washed CF-liposomes only slightly diminished within $30 \mathrm{~d}$ at $5^{\circ} \mathrm{C}$ indicating negligible leak of CF. No CF-release was seen when the temperatures was increased from $0^{\circ} \mathrm{C}$ to $22^{\circ} \mathrm{C}$ or from $0^{\circ} \mathrm{C}$ to $37^{\circ} \mathrm{C}$ for $30 \mathrm{~min}$. Thus, the CF-liposome stability was appropriate for incubation with cells. The ultrastructure of the CF-vesicles showed that the high $\mathrm{CF}$ and Na concentration induced multilayering, yielding a $330 \mathrm{~nm}$ average diameter (10). Therefore, a membrane label was used: (i) to avoid multilayering; and (ii) to be able to follow the uptake of the vesicle membranes. For this purpose, 20\% PC were replaced by Fluo-PE to form the lipid-cholate stock solution described above. Fluo-PE did not alter the ultrastructure of the vesicles (10). Fluorescent vesicles without $\mathrm{Na}, \mathrm{K}$-ATPase protein were also prepared.

\section{Isolation of Lymphocytes and Incubation with Fluorescent Vesicles}

Human blood was obtained from healthy voluntary blood donors. Peripheral blood mononuclear cells were isolated by centrifugation on a Ficoll gradient (22) in LeucoSep tubes, washed three times in HBSS, and kept in RPMI-1640 medium in the absence of serum. This procedure commonly yielded $90-95 \%$ lymphocytes and $5-10 \%$ monocytes as measured by flow cytometry. Cells were counted in a haemacytometer and viability was assessed before and after vesicle addition by Trypan blue exclusion. Increasing concentrations $(0.5$ to $200 \mu \mathrm{L})$ of vesicles were pelleted by centrifugation at $100,000 \mathrm{~g}$ in the Beckman Airfuge at $0^{\circ} \mathrm{C}, 0.5$ to 2 million peripheral blood mononuclear cells were added in 50 to $200 \mu \mathrm{L}$ RPMI-1640 or $\mathrm{PBS}$, and the suspension was incubated for $5 \mathrm{~min}$ to $2 \mathrm{~h}$ at $37^{\circ} \mathrm{C} ; 1 \mathrm{~mL}$ PBS was added, the cells pelleted for $10 \mathrm{~min}$ at $400 \mathrm{~g}$ at $20^{\circ} \mathrm{C}$ in a Sorvall H-2080 swing out rotor in a Sorvall Centrifuge RC-3B to remove the external liposomes and resuspended in $1 \mathrm{~mL}$ PBS. After incubation, the suspension was centrifuged at $400 \mathrm{~g}$ for $10 \mathrm{~min}$ at 
room temperature to remove the external liposomes and the pellet suspended in $1 \mathrm{~mL}$ PBS. Aliquots of the cell suspension were used:

1. For analysis of cellular fluorescence by flow cytometry.

2. For quantification of the intracellular Fluo-PE content by spectrofluorometry.

3. For measuring cell viability by Trypan blue exclusion.

\section{Fluorescent Techniques for Measuring Vesicle Uptake}

Cell pellets were suspended in $1 \mathrm{~mL}$ of PBS and analyzed in a Becton Dickinson FACScan (San Jose, CA). The lymphocyte and monocyte populations were differentiated by appropriate gating, excluding clusters and cell debris; 10,000 events from each cell population were analyzed. Mean cellular fluorescence and standard deviation were calculated for each sample and expressed in arbitrary fluorescence units, using the program Lysis II (Becton Dickinson). To determine the number of liposomes incorporated per cell, $100 \mu \mathrm{L}$ cell suspension as well as the supernatants recovered after the $400 \mathrm{~g}$ centrifugation step were added to $3 \mathrm{~mL}$ PBS in a quartz cuvet and the fluorescence measured in a Zeiss PMQ II ( $\lambda_{\text {ex }} 436 \mathrm{~nm}, \lambda_{\text {em }} 520$ $\mathrm{nm}) ; 10 \mu \mathrm{L}$ Triton $\mathrm{X}-100(10 \%)$ was added after the first reading to release the Fluo-PE taken up by the cell. The quantity of Fluo-PE was determined by comparison with standard curves established with pure Fluo-PE. The number of vesicles was calculated on the basis of their size and composition and amounted to $3.58 \times 10^{4} 60 \mathrm{~nm}$ vesicles $\left(\mathrm{Na}, \mathrm{K}\right.$-ATPase-free) or $1.22 \times 10^{4} 100 \mathrm{~nm}$ vesicles (with $\mathrm{Na}, \mathrm{K}$ ATPase) per mg Fluo-PE. For confocal microscopy, the cells were suspended in $10 \mu \mathrm{L}$ fixing solution, mounted as described by Lenette (21), put on a slide, and covered. Specimens were observed with a Zeiss confocal laser scan fluorescence inverted microscope (LSM 410, Carl Zeiss, Oberkochen, Germany) equipped with two different lasers: a Helium-Neon (He-Ne) laser (excitation wavelength at 543 $\mathrm{nm}$ ) and an Argon laser (excitation wavelength at $488 \mathrm{~nm}$ ). The argon laser was used to excite fluorescein and the emission spectra was detected with a photomultiplier preceded with a $510-525 \mathrm{~nm}$ narrow-band barrier filters; resulting from the $\mathrm{He}-\mathrm{Ne}$ laser, the transmission image of the specimen was obtained on a second detector. Both lasers were used separately to define for each of them the value of the optical attenuating filters. Specimens were observed through an oil plan-neofluar $\times 63 / 1.4$ objective with a zoom factor increasing the magnification 4 or 5 times. Optical sections were taken 
at $1 \mu \mathrm{m}$ intervals. The best level of section in the vertical axis was chosen through this optical sectioning. Images of $512 \times 512$ pixels were stored on an erasable optical disk (Sony Corporation, Tokyo, Japan) and then photographed on a Kodak Ektachrome Panther color slide film (100 Aza, Eastman Kodak, Rochester, NY) with a freeze-frame digital camera (Focus graphics, Geneva, $\mathrm{CH}$ ).

\section{RESULTS AND DISCUSSION}

\section{Vesicles Enter Lymphocytes in a Dose-Dependent Fashion}

FACS is a convenient technique to assess the uptake of fluorescent particles by cells (15). By appropriate window setting of the flow cytometer, the lymphocytes can be seen separately in three-dimensional (Fig. 1A) or two-dimensional (Fig. 1B,C) representation. When lymphocytes had been incubated with increasing concentrations of CF-vesicles (Fig. 1D) or Fluo-PE-vesicles (Fig. 1E,F) the lymphocyte peak shifts progressively to the right on the Log scale as the fluorescence associated with the cells increased by 1 to 3 orders of magnitude. No cells remained at the initial fluorescence level indicating that all the vesicles enter into all lymphocytes. Also, there is no appearance of cell debris or of additional peaks when cells have taken up vesicles, reflecting that their morphology and viability are preserved. In agreement with this observation, the Trypan blue analysis of the cells after incubation with fluorescent vesicles was $98.3 \%$ for the control preparation incubated without liposomes, 93.6, 85.4, 93.8, and $82.7 \%$ for cells incubated with increasing concentrations of Fluovesicles (Fig. 1E) and $86.4 \%$ for the control preparations and 83.8, 83.6 , and $71.6 \%$ for the cells incubated with increasing concentrations of Fluo-vesicles shown in Fig. 1F. The data document that all isolated human lymphocytes take up fluorescent vesicles in a dosedependent fashion without apparent toxicity.

\section{Temperature Dependence of Vesicle Entry}

Recently, we discovered that the $200 \mathrm{mM}$ CF used to label the vesicles in their water phase, in conjunction with the high Na concentration used to neutralize the acid $\mathrm{CF}$, provoked multilayering of the vesicles and augmented their diameter from the $60 \mathrm{~nm}$ of $\mathrm{Na}, \mathrm{K}-$ ATPase-free vesicles to $330 \mathrm{~nm}$ (10). We exploited the fact to have small single-walled and large, multilayered vesicles to see whether there was a difference in the temperature dependence of their uptake 

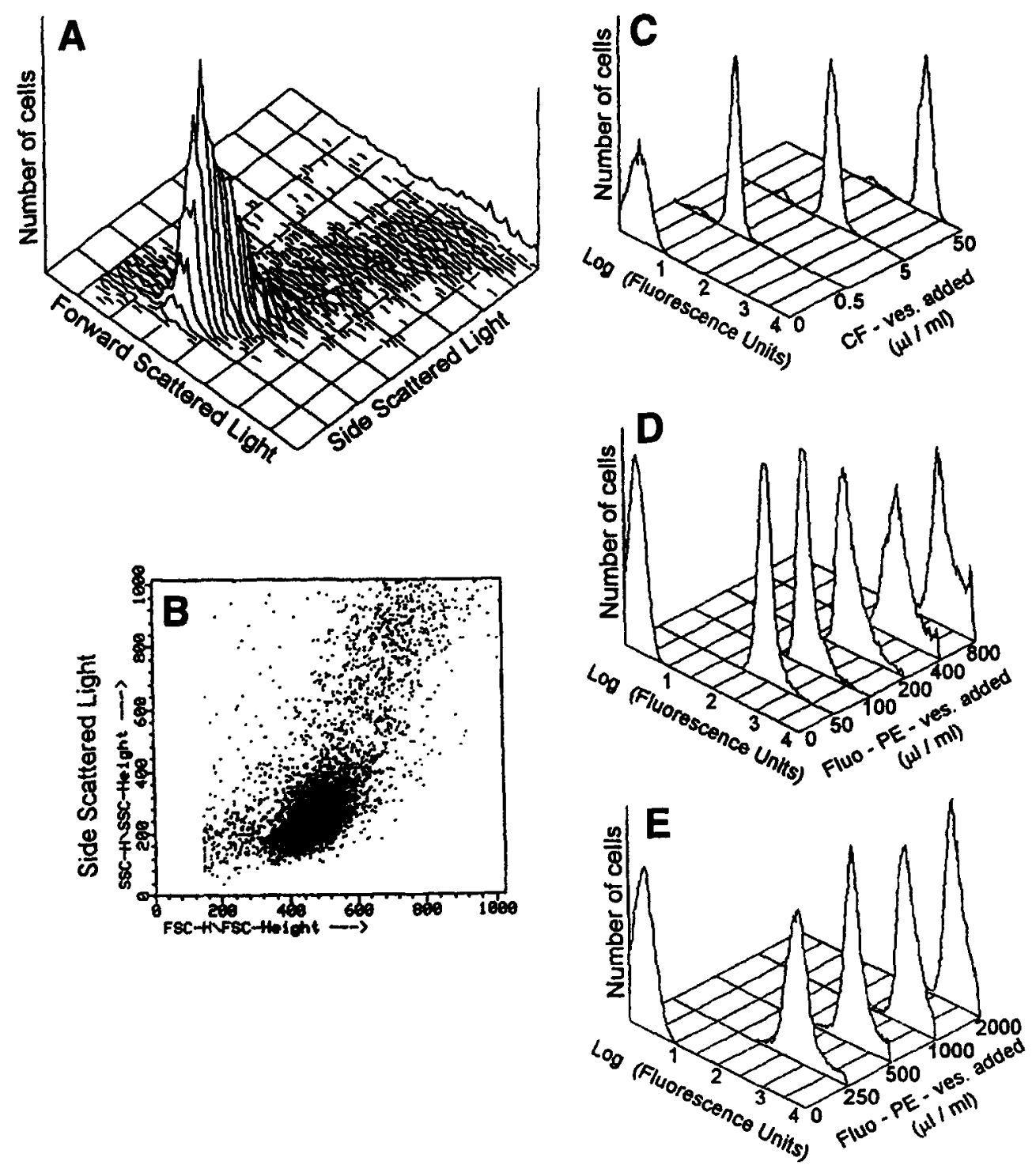

Fig. 1. Increase of cellular fluorescence with increasing vesicle/cell ratio. Freshly isolated human lymphocytes were incubated with increasing amounts of fluorescent vesicle for $30 \mathrm{~min}$ at $37^{\circ} \mathrm{C}$. The vesicle quantity added is indicated in the figure in $\mu \mathrm{L}$ of suspension that had been pelleted and added to $1 \mathrm{~mL}$ cell suspension in the conditions described in Methods; $10^{6}$ cells in $1 \mathrm{~mL}$ of PBS were added to the flow cytometer. The lymphocytes were sorted by specific window settings. Three-dimensional (A) or two-dimensional $(\mathbf{B}, \mathbf{C})$ representations of the $10^{4}$ events (cells) analyzed by scattered light shows a relatively homogenous lymphocytes population. (D) FACS analysis of lymphocytes incubated with increasing con- 
because this physical parameter is informative as to the possible mechanisms involved. The uptake of the two types of vesicles by cells incubated at 4,20 , or $37^{\circ} \mathrm{C}$ was very close (Fig. $2 \mathrm{~A}$ ) as seen clearly by the similar shifts of the fluorescence of CF-vesicles (Fig. 2B) and Fluo-vesicles (Fig. 2C) by a temperature increase form 4 to $37^{\circ} \mathrm{C}$. The $\mathrm{Q}_{10}$ of the uptake was $1.46 \pm 0.7$ (S.E.M., $n=4$ ). The temperature coefficient $\left(Q_{10}\right)$ of a reaction is the ratio of the velocity measured at a given temperature $\left({ }^{\circ} \mathrm{C}\right)$ to the velocity measured at 10 degrees below (24). The $Q_{10}$ of enzymatic reactions is generally around 2 , i.e., the velocity doubles with a $10^{\circ} \mathrm{C}$ increase of the temperature.

Such energy-requiring processes are described by an equation derived from the Van't Hoff equation (25) stating that the reaction rate $k$ is proportional to a transmission coefficient (probability that a molecule in a transition state will give the product of the reaction), and proportional to $k T / h$, which indicates the rate at which a molecule in the transition state is transformed into product (= Boltzmann constant $x$ Absolute temperature/Planck constant). By contrast, if a purely physical process were implicated such as liposome adsorption to the cell surface, the cellular fluorescence would be inversely related to temperature. According to the Gibb's law, the difference of the adsorbed amount $(\Delta \mathrm{A})$ of a compound is a function of its concentration $(\Delta \mathrm{C})$. The concentration gradient within the adsorbed layer $(\mathrm{a})=-(1 / R T) \times(\Delta A / \Delta C)$ where $R$ is the gas constant and $T$ is the absolute temperature. Thus, the high temperature dependence speaks against vesicle adsorption on the cell surface as a cause of the cell-associated fluorescence in line with the other analyses of data obtained by FACS and confocal microscopy presented herein.

\section{Na,K-ATPase in the Vesicles Does Not Interfere with Their Cellular Uptake}

Considering the rapid vesicle uptake by the isolated lymphocytes, we wished to see whether the presence of Na,K-ATPase in the vesicle membrane altered their uptake. No statistically significant differences in the cellular fluorescence measured by FACS was observed when the cells were incubated with CF-vesicles or Fluo-

centrations of CF-vesicles added to $3.7 \times 10^{6}$ cells in $200 \mu \mathrm{L}$ RPMI-1640. (E,F) Lymphocytes incubated with increasing concentrations of Fluo-PEvesicles in the experimental conditions described in Methods. 

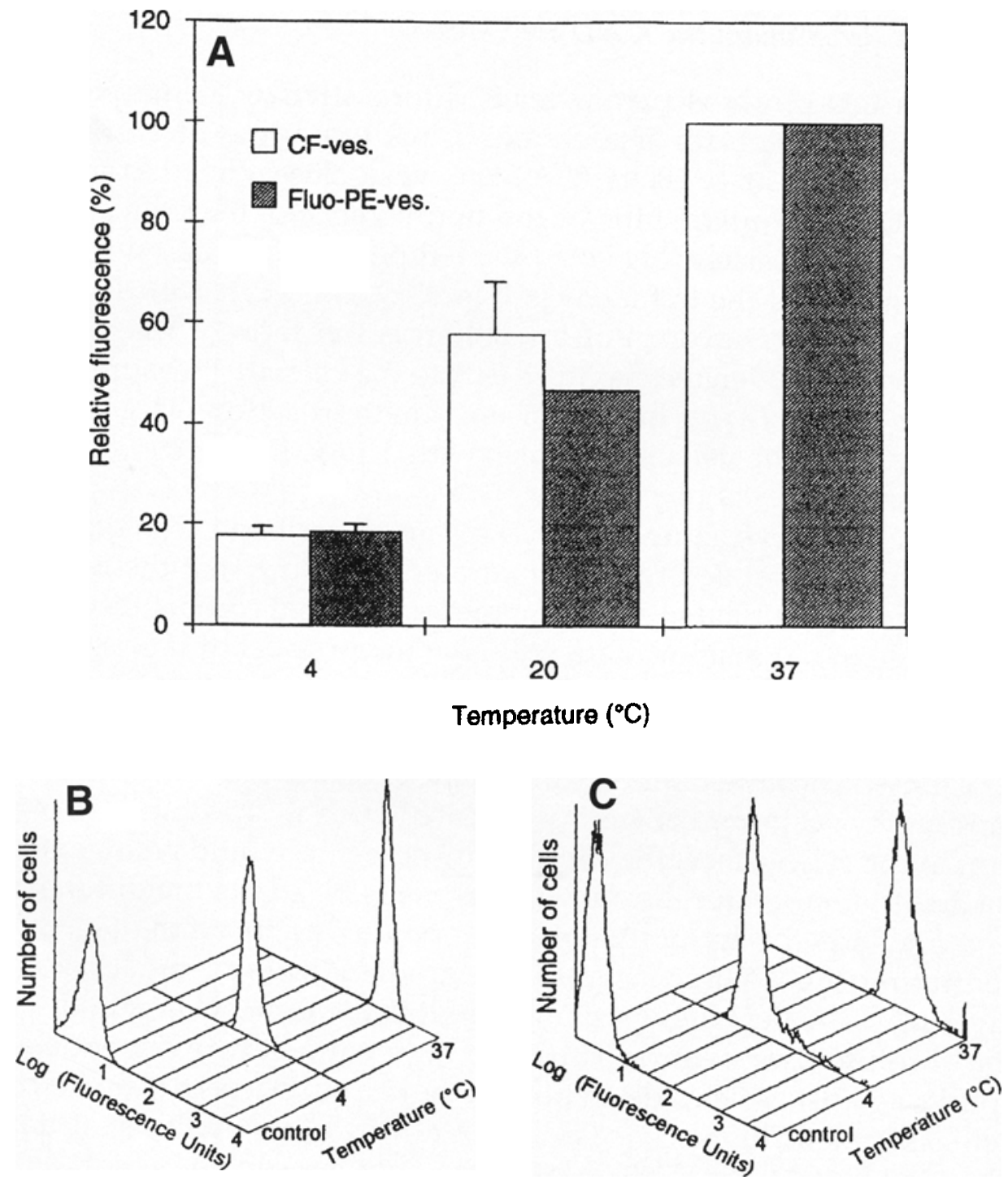

Fig. 2. Temperature-dependence of vesicle entry; $1.5 \times 10^{6}$ cells were incubated in $100 \mu \mathrm{L}$ RPMI-1640 with $50 \mu \mathrm{L} / \mathrm{mL}$ CF-vesicles (A,B) or with $50 \mu \mathrm{L} / \mathrm{mL}$ Fluo-vesicles $(\mathrm{A}, \mathrm{C})$ in $80 \mu \mathrm{L}$ PBS for $30 \mathrm{~min}$ at $37^{\circ} \mathrm{C}$. Results are expressed in percentage of the maximum fluorescence obtained in the experiment. After the incubation, cells were washed once in PBS and analyzed by FACS. Results are expressed in percentage of the maximum fluorescence obtained in the experiment. Data represent mean of two or three measurements ( \pm S.E.M.).

vesicles with or without reconstituted $\mathrm{Na}, \mathrm{K}$-ATPase (data now shown). 
Confocal microscopy was used to visualize the fluorescent vesicles taken up with or without reconstituted $\mathrm{Na}, \mathrm{K}$-ATPase. This new technique analyzes the fluorescence by a laser beam combined with powerful software for virtual sections across the cells yielding finally a three-dimensional map of the intracellular fluorescence. As the same cell is seen in fluorescent or transmission mode the intracellular fluorescence can be attributed to cellular structures in the limits of the microscopic resolution.

When cells were incubated with Fluo-vesicles without $\mathrm{Na}, \mathrm{K}-$ ATPase for 5 (Fig. 3A) or 30 (Fig. 3B) min, they became strongly fluorescent (left panels). By comparison with the transmission images (right panels), it is evident that the vesicles have entered all cells. The same result is seen with cells incubated for 5 (Fig. 3C) or 30 (Fig. 3D) min with vesicles reconstituted with $\mathrm{Na}$, K-ATPase. Obviously, the presence of renal $\mathrm{Na}$,K-ATPase in the vesicles does not prevent their uptake by all lymphocytes, in agreement with the data obtained by FACS.

That the fluorescence is not absorbed on the cell surface and is contained within the cells is shown in a typical scanned cell that has been incubated with $\mathrm{Na}$,K-ATPase-vesicles for $20 \mathrm{~min}$ (Fig. 4) and was then analyzed in three dimensions by nine virtual $1 \mu \mathrm{m}$ cross-sections. The first scan, on top of the cell, reveals no fluorescence; two small fluorescent spots became apparent on the next scanned plane; the next section, deeper within the cell, uncovers more fluorescence. The maximal fluorescence was seen in the four sections going through the middle of the cell, sparing apparently the nuclear region.

\section{Quantification of the Uptake}

To evaluate the importance of the $\mathrm{Na}, \mathrm{K}$-ATPase-vesicle entry into lymphocytes, it was important to quantify the process: how many vesicles enter and how much foreign material is imported with them expressed as a fraction of intrinsic? To answer this question, the size and composition of the vesicles as well as the size of the cell must be known and a method to quantify the internalized membranes is required. The ultrastructure of our vesicles with and without $\mathrm{Na}, \mathrm{K}$-ATPase is known $(8,9)$ and from there their content in phospholipids and $\mathrm{Na}, \mathrm{K}-\mathrm{ATP}$ ase molecules was calculated as shown in Table 1. When the number of phospholipids per vesicle is known, the internal fluorescent phospholipid can be extracted from the cell, its quantity determined by spectrofluorometry, and the vesicle num- 

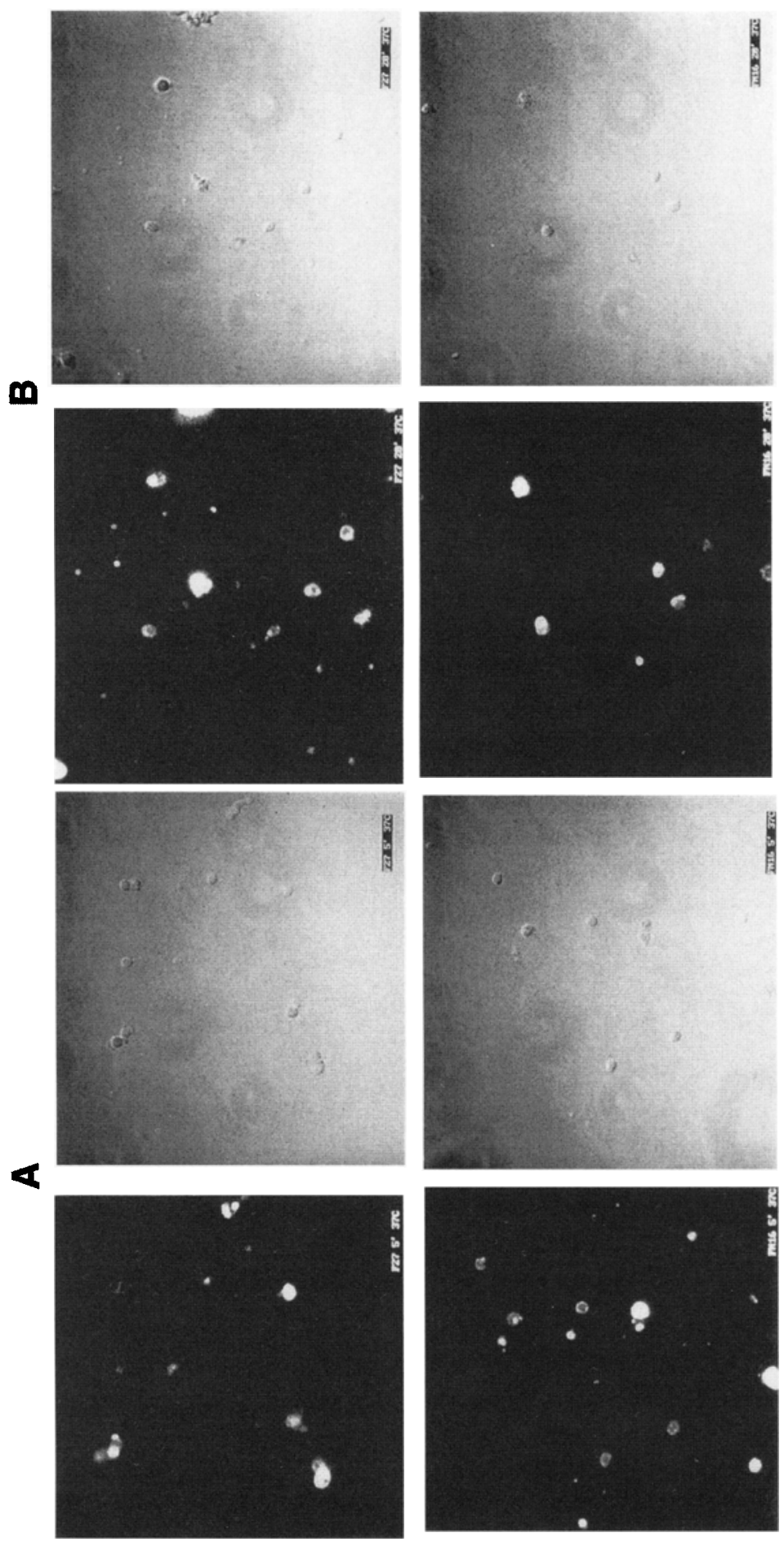

0

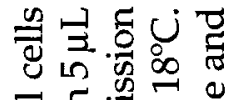
$=\simeq$.

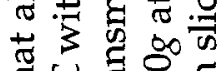

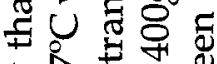
र स \& के 兵范

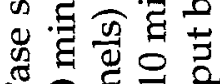

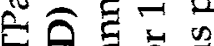

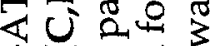
文志芯 त

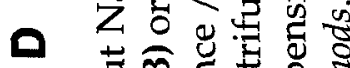

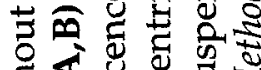
要造过

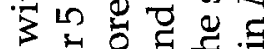
उ 娄

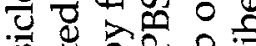
के 응 응

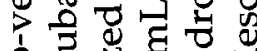
- 己 $\mathrm{N}$ 元

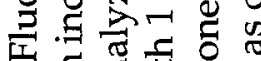
红焉 0

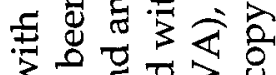
उ 웡 एक है ¿

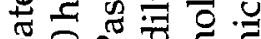

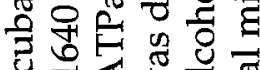
प $\frac{1}{1} \frac{7}{3}$ $\exists \theta \underline{\square}$

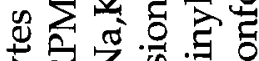

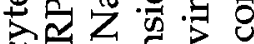
寻合各各

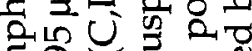
द्विर क $凵$ द्व पढ口 兵 ํำ 됴요 $5=\leq \frac{0}{5}$ 0 क

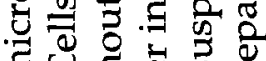

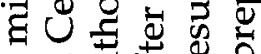
त必声焉 ชூ 융

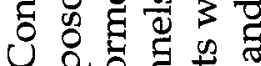
U. क क

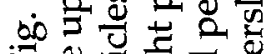

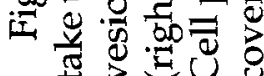

Volume 30,1999 


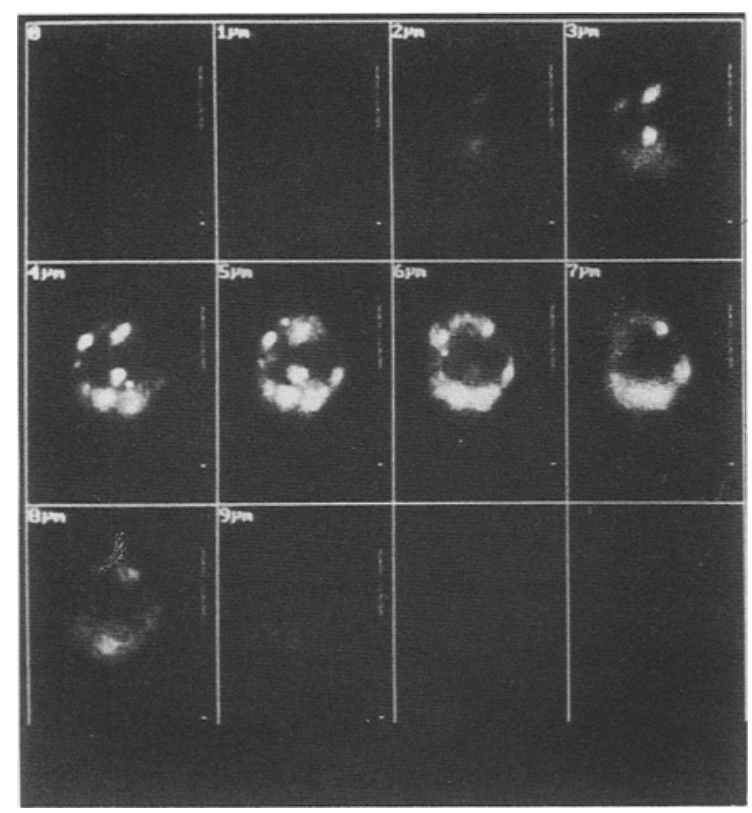

Fig. 4. Three-dimensional demonstration of intracellular fluorescence resulting from $\mathrm{Na}, \mathrm{K}-\mathrm{ATPase}$-vesicle uptake. Virtual $1 \mu \mathrm{m} \mathrm{z}$-sectioning of a typical cell that has been incubated with fluorescent vesicles for $20 \mathrm{~min}$ in the conditions described for Fig. 3.

ber taken up per cell calculated. However, the lymphocytes are contaminated by monocytes, which are phagocytic cells and take up more vesicles than lymphocytes. The average percentage of monocytes present in the preparation was determined by FACS in a series of three different preparations ( \pm S.E.M.) to which $5 \mu \mathrm{L} \mathrm{CF-liposomes}$ had been added (to $2 \times 10^{6}$ cells in $100 \mu \mathrm{L} \mathrm{RPMI}-1640$ at $37^{\circ} \mathrm{C}$ ): $8.3 \pm$ $0.1 \%, 8.7 \pm 0.6 \%, 9.1 \pm 0.1 \%, 9.4 \pm 0.3 \%$, and $10.3 \pm 0.3 \%$ after 5,10 , 30,60 , and $120 \mathrm{~min}$ of vesicle addition, respectively. An average value of $9 \%$ was chosen for the calculations.

With regard to the vesicle uptake, the following monocyte/lymphocyte fluorescence ratios were obtained in triplicates ( \pm S.E.M.) in six different preparations that incorporated, respectively, $36 \pm 1.5$, $28 \pm 1,27 \pm 3,17 \pm 0.3,23 \pm 0.2$, and $10 \pm 0.3$ times more fluorescence within $60 \mathrm{~min}$ at $37^{\circ} \mathrm{C}$; the average of the six separate determinations was 23 . On the basis of the $9 \%$ monocyte fraction and the $23-$ fold difference of uptake by lymphocytes and monocytes, the distribution of Fluo-PE-liposomes between monocytes and lympho- 
Table 1

Parameters Used for Quantifying Vesicle Uptake

\begin{tabular}{|c|c|c|}
\hline \multirow[t]{3}{*}{ Average diameter } & Lymphocyte & $10 \mu \mathrm{m}^{a}$ \\
\hline & $\mathrm{Na}, \mathrm{K}-\mathrm{ATPa}$-vesicle total & $100 \mathrm{~nm}^{b}$ \\
\hline & Inner compartment ( $-4 \mathrm{~nm}$ membrane) & $92 \mathrm{~nm}$ \\
\hline \multirow[t]{3}{*}{ Phospholipid No. } & per $100 \mathrm{~nm}$ vesicle outer leaflet & 44,882 \\
\hline & inner leaflet & 37,988 \\
\hline & total & 82,870 \\
\hline \multirow[t]{3}{*}{ Surface } & Lymphocyte & $3.14 \times 10^{-10} \mathrm{~m}^{2}$ \\
\hline & Na,K-ATPase-vesicle & $3.14 \times 10^{-14} \mathrm{~m}^{2}$ \\
\hline & PC headgroup & $0.7 \times 10^{-18} \mathrm{~m}^{2 c}$ \\
\hline \multirow[t]{2}{*}{ Volume } & Lymphocyte & $5.24 \times 10^{-16} \mathrm{~m}^{3}$ \\
\hline & Na,K-ATPase-vesicles & $4.08 \times 10^{-22} \mathrm{~m}^{3}$ \\
\hline
\end{tabular}

${ }^{a}$ The average cell size was estimated by optical and electronic microscopy and found compatible with published data (28).

${ }^{b}$ The vesicle size was determined by freeze fracture $(8,9)$ and transmission electronic microscopy (10).

${ }^{c}$ The diameter of a phosphatidylcholine headgroup was found in the work of Mimms et al. (29).

cytes was calculated considering that $9 \%$ of the cells (monocytes) take up 23 parts of the fluorescence and $91 \%$ of the cells (lymphocytes) take up one part, which is equivalent to $72 \%$ of vesicles taken up by monocytes and $28 \%$ by lymphocytes. When this correction ismade, the number of vesicles incorporated per lymphocytes at increasing vesicle/cell ratios amounts to the values listed in Table 2 . By combining these data with the data of Table 1, the amount of internalized membrane and volume was also calculated, as well as the number of $\mathrm{Na}, \mathrm{K}-\mathrm{ATPase}$ molecules (Table 2).

In previous work, the vesicular $\mathrm{Na}, \mathrm{K}-\mathrm{ATPase}$ was radiolabeled by ${ }^{110 \mathrm{~m}} \mathrm{Ag}$. The cells were then incubated with the ${ }^{110 \mathrm{~m}} \mathrm{Ag}$-labeled $\mathrm{Na}, \mathrm{K}$-ATPase-vesicles, washed in presence of external dimercaptopropanesulfonic acid (DMPS) to remove all external silver and the ${ }^{110 \mathrm{~m} A g}$ taken up by the cells was counted. According to previous determinations, there were four molecules $\mathrm{Na}, \mathrm{K}$-ATPase per liposome at the protein/lipid ratio used and, in conjunction with the value of 2 silver ions bound per $\mathrm{Na}, \mathrm{K}-\mathrm{ATP}$ ase molecule, the number of liposomes incorporated was found to be $3114 \pm 215$ (S.E.M., $n=$ 21) for an incubation period of $120 \mathrm{~min}$ at $35^{\circ} \mathrm{C}$ at a liposome/cell ratio of $3 \cdot 1 . \times 10^{5}(26,27)$. Thus, two entirely different methods yield 
Table 2

Foreign Material Brought to a Lymphocyte by Vesicle Uptake for 30 Min

\begin{tabular}{|c|c|c|c|c|c|c|}
\hline $\begin{array}{l}\text { Vesicles } \\
\text { entered }\end{array}$ & Foreign $\mathrm{m}$ & mbrane & Foreign vo & lume & Foreign $\mathrm{Na}$ & K-ATPase \\
\hline Number & $\left(\mathrm{m}^{2}\right)$ & $\begin{array}{c}(\% \text { of } \\
\text { intrinsic) }\end{array}$ & $\left(\mathrm{m}^{3}\right)$ & $\begin{array}{c}\text { (\% of } \\
\text { intrinsic) }\end{array}$ & No. & $\begin{array}{c}\% \text { of } \\
\text { intrinsic }\end{array}$ \\
\hline $1910^{a}$ & $2.158 \times 10^{-11}$ & 7 & $1.406 \times 10^{-19}$ & 0.03 & 11,460 & 38 \\
\hline $4122^{a}$ & $4.658 \times 10^{-11}$ & 15 & $3.035 \times 10^{-19}$ & 0.06 & 24,732 & 82 \\
\hline $8748^{a}$ & $9.885 \times 10^{-11}$ & 32 & $6.440 \times 10^{-19}$ & 0.12 & 52,488 & 175 \\
\hline $16,087^{a}$ & $1.818 \times 10^{-10}$ & 60 & $1.184 \times 10^{-18}$ & 0.23 & 96,522 & 322 \\
\hline $39,414^{a}$ & $4.454 \times 10^{-10}$ & 142 & $2.902 \times 10^{-18}$ & 0.55 & 236,484 & 788 \\
\hline $18,098^{b}$ & $2.045 \times 10^{-10}$ & 65 & $1.332 \times 10^{-18}$ & 0.25 & 108,588 & 362 \\
\hline $19,004^{b}$ & $2.147 \times 10^{-10}$ & 68 & $1.399 \times 10^{-18}$ & 0.27 & 114,024 & 380 \\
\hline $41,526^{b}$ & $4.692 \times 10^{-10}$ & 149 & $3.057 \times 10^{-18}$ & 0.58 & 249,156 & 830 \\
\hline $106,982^{b}$ & $1.208 \times 10^{-9}$ & 385 & $7.876 \times 10^{-18}$ & 1.50 & 641,892 & 2140 \\
\hline
\end{tabular}

Two different Fluo-vesicle preparations (a) and (b) were pelleted and incubated with $1.4 \times 10^{6}$ cells for $30 \mathrm{~min}$ at $37^{\circ} \mathrm{C}$, resulting in ratios of $0.27,0.59,1.58,3.99$, and $8.88 \times 10^{5}$ (a) and $0.6,1.1,1.8$, and $4.7 \times 10^{6}$ vesicles (b) per cell. After the incubation, the cells were processed and the entrapped Fluo-PE measured by spectrofluorometry as described in Methods and calculated according to the data of Table 1 . The number of $6 \mathrm{Na}, \mathrm{K}$-ATPase molecules per vesicle was taken from previous determinations of freeze fractured preparation prepared in the same conditions. A number of $30,000 \mathrm{Na}, \mathrm{K}-$ ATPase molecules per lymphocyte had been determined by ${ }^{3} \mathrm{H}$-ouabain (30).

close values for the number of $\mathrm{Na}, \mathrm{K}-\mathrm{ATPase}$-vesicles incorporated per cell.

It is impressive that a lymphocyte incubated in the presence of 4.7 million externally added $\mathrm{Na}, \mathrm{K}$-ATPase vesicles has taken up 3.85 times its own membrane surface, replaced $1.5 \%$ of its volume by foreign solution, and taken up more than 20 times more foreign $\mathrm{Na}$, $\mathrm{K}-$ ATPase as compared to the intrinsic number (Table 2).

\section{ACKNOWLEDGMENTS}

The authors thank Dominique Wohlwend of the Cytofluorographic Center, Geneva University Medical School, for assistance with FACS analysis, Ch. Burrus and D. Lacotte for help with confocal and electron microscopy, and M. Moosmayer for assistance with $\mathrm{Na}, \mathrm{K}-\mathrm{ATPase}$ purification and reconstitution. This research was supported by the Swiss National Science Foundation, Grants No. 3125666.88 and 31-37552.93 and by the Swiss Public Health Office, Grant No. 90-7052. 


\section{REFERENCES}

1. Hamm-Alvarez, A. F., Wei, X., Berndt, N., and Runnegar, M. (1996) Protein phosphatase independently regulate vesicle movement and microtubule subpopulations in hepatocytes. Am. J. Physiol. 271, C929-C942.

2. Sion, J.-P., Ivanov, I. E., Adesnik M., and Sabatini, D. D. (1996) The production of post-Golgi vesicles requires a protein kinase C-like molecule, but not its phosphorylating activity. J. Cell Biol. 135, 355-370.

3. Levenson, R. (1994) Isoforms of the Na,K-ATPase: family members in search of function. Rev. Physiol. Biochem. Pharmacol. 123, 1-45.

4. Blaustein, M. P. (1993) Physiological effects of endogenous ouabain: control of intracellular Ca2+ stores and cell responsiveness. Am. J. Physiol. 264, C1367-C138.

5. Lees, G. J. (1991) Inhibition of sodium-potassium-ATPase: a potentially ubiquitous mechanism contributing to central nervous system neuropathology. Brain Res. Rev. 16, 283-300.

6. Li, K. and Sperelakis, N. (1994) Electrogenic Na-K pump current in rat skeletal myoballs. J. Cell Physiol. 159, 181-186.

7. Goldin, S. M. (1974) Reconstitution of active transport catalyzed by the purified sodium and potassium ion-stimulated adenosine triphosphatase from canine renal medulla. J. Biol. Chem. 248, 5907-5915.

8. Anner, B. M., Ting-Beall, H. P., and Robertson, J. D. (1984) Characterization of $(\mathrm{Na}+\mathrm{K})$-ATPase liposomes. I. Effect of enzyme concentration and modification on liposome size, intramembrane particle formation and $\mathrm{Na}, \mathrm{K}$-transport. Biochim. Biophys. Acta 773, 253-261.

9. Anner, B. M., Robertson, J. D., and Ting-Beall, H. P (1984) Characterization of $(\mathrm{Na}+\mathrm{K})$-ATPase liposomes. II. Effect of alpha-subunit digestion on intramembrane particle formation and $\mathrm{Na}$,K-transport. Biochim. Biophys. Acta 773, 262-270.

10. Volet, B., Lacotte, D., Moosmayer, M., and B. M. Anner. (1994) Na,KATPase or carboxyfluorescein alter vesicle formation in vitro. Biochim. Biophys. Acta, 1191, 1-6.

11. Weinstein, J. N., Yoshikami, S., HeNa,K-ATPasert, P., Blumenthal, R. and W. A. Hagins. (1977) Liposome-cell interaction: transfer and intracellular release of a trapped fluorescent marker. Science 195, 489-492.

12. Blumenthal, R., Weinstein, J. N., Sharrow, S. O. and P. HeNa,KATPasert. (1977) Liposome-lymphocyte interaction: Saturable sites for transfer and intracellular release of liposome contents. Proc. Natl. Acad. Sci. USA 74, 5603-5607. 
13. Lee K.-D., Nir S., and D. Papahadjopoulos D. (1993) Quantitative analysis of liposome-cell interactions in vitro: rate constants of binding and endocytosis with suspension and adherent $J 774$ cells and human monocytes. Biochemistry 32, 889-899.

14. Lee, K-D., Hong, K., and Papahadjopoulos, D. (1992) Liposomes recognition by cells: In vitro binding and endocytosis mediated by specific headgroups and surface charge density. Biochim. Biophys. Acta 1103, 185-197.

15. Leroux, J.-C., Gravel, P., Balant, L., Volet, B., Anner, B. M., Alléman, E., Doelker, E., and Gurny, R. (1994) Internalization of poly(D,Llactic acid) nanoparticles by isolated human leukocytes and analysis of plasma proteins adsorbed onto the particles. J. Biomed. Mat. Res. 28, 471-481.

16. Dzhandzhugazyan, K. N. and Jørgensen, P. L. (1985) Asymmetric orientation of amino groups in the $\alpha$-subunit and the $\beta$-subunit of $\left(\mathrm{Na}^{+}+\mathrm{K}^{+}\right)$- ATPase in tight right-side-out vesicles of basolateral membranes from outer medulla. Biochim. Biophys. Acta 817, 165-173.

17. Anner, B. M., Moosmayer, M., and Imesch, E. (1994) Na,K-ATPase characterised in artifical membranes. 1. Predominant conformations and ion fluxes associated with active and inhibited states. Mol. Membrane Biol. 11, 237-245.

18. Smith, P. K., Krohn, R. I., Hermanson, G. T., Mallia, A. K., Gartner, F. H., Provenzano, M. D., Fujimoto, E. K., Goeke, N. M., Olson, B. J., and D. C. Klenk. (1985) Measurement of protein using bicinchoninic acid. Anal. Biochem. 150, 76-85.

19. Szoka, F. C., Jacobson, K., and Papahadjopoulos, D. (1979) The use of aqueous space markers to determine the mechanism of interaction between phospholipid liposomes and cells. Biochim. Biophys. Acta 551, 295-303.

20. Ralston, E., Blumenthal, R., Weinstein, J. N., Sharrow, S. O., and He, P. (1980) Na,K-ATPasert lysophosphatidylcholine in liposomal membranes. Enhanced permeability but little effect on transfer of a water-soluble fluorescent marker into human lymphocytes. Biochim. Biophys. Acta 597, 543-551.

21. Collins, D., Litzinger, D. C., and Huang, L. (1990) Structural anf functional comparisons of $\mathrm{pH}$-sensitive liposomes composed of phosphatidylethanolamine and three different diacylsuccinylglycerols. Biochim. Biophys. Acta 1025, 234-242.

22. Bøyum A. (1968) Isolation of mononuclear cells and granulocytes from human blood. Scand. J. Clin. Lab. Invest. 21,Suppl. 97, $77-89$.

23. Lenette, D. A. (1978) An improved mounting medium for immunofluorescence microscopy. Am. J. Pathol. 69, 647-648. 
24. Dawes, E. A. (1972) Quantitative Problems in Biochemistry. Williams and Wilkin, Baltimore, MD, pp. 165-183.

25. Gutfreund, H. (1975) Enzymes: Physical Principles. Wiley, London, New York. pp. 161-165.

26. Anner, B. M., Meneghini, E., Hussain, S., Lacotte, D. and Moosmayer, M. (1994). Interaction of radiolabeled Na,K-ATPase-liposomes with human peripheral blood mono-nuclear cells. Biochim. Biophys. Acta 1194, 345-348.

27. Hussain, S., Meneghini, E, Moosmayer, . M., Lacotte, D. and Anner, B. M. (1994) Potent and reversible interaction of silver with pure $\mathrm{Na}, \mathrm{K}-\mathrm{ATPase}$ and Na,K-ATPase-liposomes. Biochim. Biophys. Acta 1190, 402-408.

28. Falciola, J., Volet, B., Anner, R. M., Moosmayer, M., Lacotte, D., Anner, B. M. (1994) Role of cell membrane Na,K-ATPase for survival of human lymphocytes in vitro. Biosci. Rep. 14, 189-204.

29. Mimms, L. T., Zampighi, G., Nozaki, Y., Tanford, Ch., and J. A. Reynolds. (1981) Phospholipid vesicle formation and transmembrane protein incorporation using octyl glucoside. Biochemistry 20, 833-840.

30. Pedersen, K. E., and N. A. Klitgaard. (1983) Influence of quinidine on the binding of $[3 \mathrm{H}]$-ouabain and $[3 \mathrm{H}]$-digoxin by human lymphocytes. Eur. J. Clin. Pharmacol. 25, 263-270. 